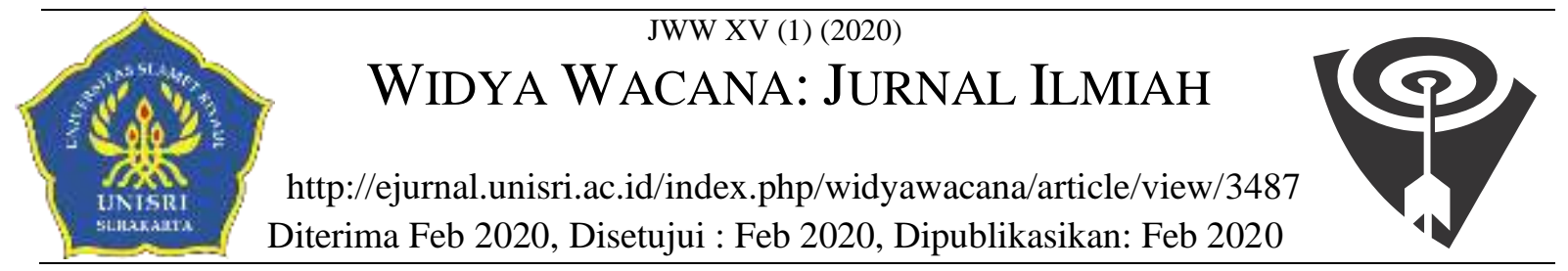

\title{
MEMAKNAI KEADILAN BERDASARKAN KETUHANAN YANG MAHA ESA DITUNJAU DARI PERSPEKTIF PENDIDIKAN KEWARGANEGARAAN
}

\author{
Agil Nanggala \\ Universitas Pendidikan Indonesia \\ E-mail: Nanggala34@gmail.com
}

\begin{abstract}
ABSTRAK
Memaknai keadilan di Indonesia merupakan perkara yang mustahil apabila tidak berdasar pada kekuatan Tuhan yang Maha Esa. Mengapa keadilan tidak kunjung terwujud, karena penafsiran keadilan selalu digunakan melalui pendekatan formalistik dan positivis. Keadilan berdasarkan Ketuhanan yang Maha Esa merupakan kajian filosofik sebagai kritik sosial sekaligus refleksi dalam penegakan hukum di Indonesia. Penelitian ini menggunakan pendekatan kualitatif, dengan metode penelitian studi literatur. Meninjau keadilan yang berdasar Ketuhanan yang Maha Esa dari perspektif Pendidikan Kewarganegaraan adalah bagaimana keadilan berdasarkan Ketuhanan yang Maha Esa dielaborasikan dengan keilmuan Pendidikan Kewarganegaraan, guna mendapatkan keadilan yang mampu merepresentasikan nilai-nilai Ketuhanan dalam masyarakat multikultural. Pendidikan Kewarganegaraan memiliki posisi yang sangat strategis dalam kurikulum nasional. Posisi tersebut harus dimanfaatkan sebaik mungkin, dalam membentuk mental peserta didik yang memiliki nilai keadilan yang berdasar pada Ketuhanan yang Maha Esa.
\end{abstract}

Kata Kunci: Ketuhanan yang Maha Esa, Keadilan, Pendidikan Kewarganegaraan.

\begin{abstract}
To interpret justice in Indonesia is impossible when not based on the power of the Almighty God. Why justice is not materialized, because the interpretation of justice is always used through formalistic and positivity approaches. Justice based on the almighty Godhead is a philosophical study as a social criticism as well as a reflection in the law enforcement in Indonesia. The study used a qualitative approach, with research methods of literature studies. Reviewing the justice of the Almighty Godhead from the perspective of citizenship education is how justice based on the almighty Godhead is elaborated on the science of Citizenship education, in order to obtain the justice Able to represent the values of the Godhead in multicultural societies. Citizenship education has a very strategic position in the national curriculum. The position must be utilized in the best possible, in the mental form of learners who have the value of justice based on the almighty Godhead.
\end{abstract}

Keywords: The almighty Godhead, justice, citizenship education.

\section{PENDAHULUAN}

Mewujudkan keadilan di Indonesia merupakan perkara yang mustahil apabila tidak dimaknai dengan konsep keadilan berdasar pada Ketuhanan yang Maha Esa. Mengapa keadilan tidak kunjung terwujud dalam kehidupan berbangsa dan bernegara, karena penafsiran keadilan selalu digunakan melalui pendekatan formalistik dan positivis. Keadilan berdasarkan Ketuhanan yang Maha
Esa merupakan kajian filosofi sebagai kritik sosial sekaligus refleksi dalam penegakan hukum di Indonesia.

Kesadaran hukum warga negara merupakan faktor penting dalam terselenggaranya kehidupan berbangsa dan bernegara yang adil, damai dan makmur. Tetapi tidak jarang ditemukan kenyataan bahwa hukum positif Indonesia tidak sesuai dengan nilai-nilai yang hidup di masyarakat. 
Idealnya pembuatan hukum tertulis di Indonesia harus benar-benar berdasarkan nilai-nilai Ketuhanan serta nilai yang hidup dimasyarakat, agar tidak terjadi ketimpangan hukum secara konsep dan teoritik, sehingga tidak menjadi problematika konseptual mengapa keadilan tidak kunjung terealiasikan.

Nilai Ketuhanan dalam Pancasila menjadi kausa prima dalam mendasari silasila Pancasila. Konsep tersebut telah dirumuskan dengan penuh kebijaksanaan dan kehikmatan oleh founding father, sebagai warisan luhur bagi generasi penerus bangsa. Sehingga tugas kita bersama mengkajinya secara filosofik dan akademis dengan menggunakan pendekatan Ketuhanan yang Maha Esa. Penafsiran dan penegakan hukum akan kuat, dan tidak menimbulkan resistensi dalam masyarakat apabila semangat dan kehendaknya tidak bertentangan dengan nilainilai Ketuhanan.

Pendidikan Kewarganegaraan sebagai pendidikan hukum, harus menjadi dispilin ilmu yang strategis dalam membahas keadilan hukum yang berdasar pada Ketuhanan yang Maha Esa. Sehingga mampu menjadi tinjauan akademik mengapa keadilan hukum sampai saat ini masih jauh dari kata ideal serta bagaimana melaksanaakan pendekaan hukum kepada masyarakat yang penuh dengan nilai kemanusiaan. Pendidikan Kewarganegaraan sebagai mata pelajaran dan mata kuliah wajib yang harus ditempuh seorang kaum intelektual memiliki posisi kuat dalam menyebarkan nilai-nilai keadilan kepada peserta didik.

Harapannya dengan meninjau keadilan berdasarkan Ketuhanan yang Maha Esa mampu menjadi kajian akademik yang komprehensif dalam memecahkan masalah keadilan di Indonesia.

\section{METODOLOGI PENELITIAN}

Penelitian ini menggunakan pendekatan kualitatif, dengan metode penelitian studi literatur, agar mampu mengkaji secara teliti konsep dan makna keadilan berdasarkan pada Ketuhanan yang Maha Esa, ditinjau dari Perspektif Pendidikan Kewarganegaraan.

Peneliti memiliki paradigma pemikiran bahwa konsep Keadilan berdasar pada Ketuhanan yang Maha Esa, merupakan konsep sangat luhur, sehingga manusia tidak memiliki kekuatan utuk menggapai keadilan tersebut, tanpa petunjuk dan ridho Tuhan yang Maha Esa.

\section{PEMBAHASAN}

1). Bagaimana konsep Keadilan yang Maha Esa ditinjau dari Perspektif Pendidikan Kewarganegaraan?

Meninjau keadilan berdasarkan Ketuhanan yang Maha Esa dari perspektif Pendidikan Kewarganegaraan, merupakan pekerjaan yang kompleks, tetapi disini peneliti mencoba mengkajinya secara komprehensif, dengan memohon bantuan, dan ridho dari Tuhan yang Maha Esa.

Konsep keadilan sendiri merupakan konsep yang subjektif, terlebih apabila berdasarkan Ketuhanan yang Maha Esa. Sehingga peneliti beranggapan para pendidik hukum, dan penegak hukum apabila ingin mewujudkan keadilan berdasarkan Ketuhanan yang Maha Esa, harus memiliki kebijaksanaan dan kehikmatan yang tinggi, mereka harus sadar bahwa Tuhan merupakan penguasa paling tinggi di alam semesta, sekaligus merupakan hakim yang paling adil. Kebijaksanaan tersebut akan menjadi intuisi dalam menafsirkan konsep keadilan berdasar pada Ketuhanan yang Maha Esa.

Secara teoritik Lihawa (2018 : 5) Menjelaskan sebelum mengetahui konsep keadilan yang berdasarkan pada asas Ketuhanan yang Maha Esa, terlebih dahulu kita perlu mengetahui bahwa mayoritas masyarakat percaya bahwa keadilan hukum merupakan konsep yang bersifat abstrak dan subyektif, sulit didefinisikan, terlebih 
berdasar pada Ketuhanan yang Maha Esa. Tetapi kita perlu meyakini bahwa keadilan merupakan inti hukum, yang merepresentasikan nilai-nilai ketauhidan sebagai sumber kekuatan dalam menafsirkan peristiwa hukum, serta melaksanakan penegakan hukum yang humanis. Keyakinan tersebut mengantarkan penegak hukum untuk memiliki integritas tinggi dalam mengatasi kasus hukum.

Termaktub jelas pada pembukaan Undang-undang Dasar 1945, yang dijewantahkan pada Pasal 29 UUD 1945 bahwa Indonesia merupakan negara yang berdasar pada Ketuhanan yang Maha Esa. Tentu cara memaknai dan cara menegakan hukumnya pun harus memiiki semangat yang tidak berlawanan dengan kehendak Tuhan yang Maha Kuasa.

Dalam menafsirkan keadilan berdasar pada Ketuhanan yang Maha Esa. Manusia harus melihat dan merefleksikan fenomena hukum secara seksama dan penuh kebijaksaaan. Maka wajiblah penegak hukum khususnya dan pendidik hukum umumnya harus memiliki moralitas tinggi, sehingga tafsir dari setiap peristiwa hukum selalu mendapatkan ridho dari Tuhan yang Maha Kuasa. Penegakan hukum yang tidak menimbulkan resistensi dari masyarakat akibat tafsir hukum yang tidak adil, akan selalu terkenang, serta mendapatkan penghormatan yang tinggi dari masyarakat, yang akhirnya berpengaruh pada kepercayaan publik terhadap aparat penegak hukum disuatu negara.

Faktanya pendidikan hukum merupakan kajian yang merefleksikan mengapa hukum semakin jauh dari nilai-nilai keadilan, dan menganalisis ketidakpuasan masyarakat akibat dari keputusan hukum yang tidak adil semakin meningkat. Ditinjau dari ranah akademik, kajian ilmiah yang memperkaya teori mengenai pendidikan hukum dirasa masih kurang, setidaknya pendekatan keadilan hukum yang berdasarkan Ketuhanan yang Maha Esa telah menjadi alternatif kajian baru dalam memahami konsep hukum.

Pendidikan Kewarganegaraan yang memiliki andil kuat dalam mensosialisasikan hukum kepada peserta didik. Atas perannya sebagai pendidikan hukum, PKn harus mampu membentuk warga negara yang sadar dan menaati hukum, sebagai atribut warga negara yang cerdas dan baik.

Sutrisno (2018 : 43) Menegaskan pembelajaran PKn memiliki peran dan fungsi, yaitu menanamkan paham ideologi Pancasila, yang memiliki nilai berdasar pada ketuhanan, kemanusiaan, persatuan, musyawarah berhikmat, dan keadilan sosial. Sebagai pedoman hidup warga negara Indonesia, sehingga mampu melaksanakan hak dan kewajibannya, serta berkompeten untuk menjadi agen keadilan.

Partispasi warga negara merupakan faktor penting dalam mewujudkan Keadilan berdasar pada Ketuhanan yang Maha Esa, karena demokrasi tanpa hukum akan anarkis, dan hukum tanpa demokrasi akan elitis. Samsuri (dalam Sulianti, 2018 : 49) Menegaskan Pendidikan Kewarganegaraan memiliki tujuan untuk meningkatkan partisipasi warga negara yang bermutu, serta bertanggung jawab mewujudkan masyarakat Indonesia yang memahami hukum, maka haruslah warga negara memiliki sejumlah kompetensi, yang direpresentasikan melalui tiga komponen pembelajaran PKn yaitu, civic knowledge, civic skills, dan civic dispositions.

Sebagai pendekatan keilmuan yang interdispliner, Pendidikan Kewarganegaraan berkompeten untuk disebut sebagai pendidikan hukum, dan pendidikan multikuktural. Maftuh (2008 : 137) menjelaskan Pendidikan Kewarganegaraan sebagai pendidikan hukum, karena memiliki tujuan dalam membina siswa sebagai warga negara untuk memiliki kesadaran dan kepatuhan hukum yang tinggi, serta 
memahami hak dan kewajibannya sebagai warga negara yang baik.

Selanjutnya Maftuh (2008 : 137) menegaskan Pendidikan Kewarganegaraan sebagai pendidikan multikulural, karena dispilin ilmu tersebut mampu meningkatkan wawasan dan toleransi peserta didik sehingga menerima fakta bahwa Indonesia merupakan bangsa yang multikultural, serta mampu untuk hidup bersama yang dilandasi rasa saling menghormati dan menghargai.

Memaknai keadilan yang berdasar Ketuhanan yang Maha Esa dari perspektif Pendidikan Kewarganegaraan adalah bagaimana konsep keadilan berdasarkan Ketuhanan yang Maha Esa dielaborasikan dengan keilmuan Pendidikan Kewarganegaraan, guna mendapatkan keadilan yang mampu merepresentasikan nilai-nilai Ketuhanan dalam masyarakat multikultural. Termaktub jelas dalam pembukaan Undang-undang Dasar 1945, bahwa negara wajib melindungi dan mengakomodir kesejahteraan bangsa tanpa melihat latar belakang apa pun.

Indonesia menjadi bangsa yang multikultural, karena merupakan kodrat dari Tuhan yang Maha Kuasa. Sehingga dalam mewujudkan keadilan berdasarkan Ketuhanan yang Maha Esa pada bangsa yang multikultural tentu harus diiringi dengan semangat kemanusiaan, karena konsep keadilannya harus mampu mewujudkan masyarakat Indonesia yang beradab.

Kajian filosofi mengenai keadilan tersebut merupakan refleksi dari fenomena hukum yang semakin jauh dari nilai-nilai keadilan. Serta menjadi solusi alternatif dalam memaknai hukum yang dilandasi oleh Keadilan berdasar pada Ketuhanan yang maha Esa, guna menghindari resistensi akibat keputusan hukum yang dianggap tidak adil, baik oleh hati nurani maupun nilai-nilai yang hidup dalam masyarakat.
2). Bagaimana posisi Pendidikan Kewarganegaraan dalam membentuk peserta didik agar menjadi agen keadilan bangsa berdasarkan pada Ketuhanan yang Maha Esa?

Ditinjau secara yuridis pada UU No. 20 Tahun 2003 tentang Sistem Pendidikan Nasional, bahwa tujuan Pendidikan Kewarganegaraan adalah untuk membekali peserta didik dengan pengetahuan dan kemampuan dasar berkenaan dengan hubungan warga negara serta pendidikan pendahuluan bela negara agar menjadi warga negara yang dapat diandalkan oleh bangsa dan negara. Pendidikan Pancasila mengarahkan perhatian pada karakter dan moral yang diharapkan diwujudkan dalam kehidupan sehari-hari, yaitu:

1) Perilaku yang memancarkan iman dan taqwa terhadap Tuhan yang Maha Esa dalam masyarakat yang terdiri dari berbagai golongan agama.

2) Perilaku yang bersifat kemanusiaan yang adil dan beradab.

3) Perilaku yang mendukung persatuan bangsa dalam masyarakat yang beraneka ragam kebudayaan dan beraneka ragam kepentingan.

4) Perilaku yang mendukung kerakyatan yang mengutamakan kepentingan bersama di atas kepentingan perorangan dan golongan sehingga perbedaan pemikiran, pendapat, ataupun kepentingan diatasi melalui musyawarah dan mufakat.

5) Serta perilaku yang mendukung upaya untuk mewujudkan keadilan sosial bagi seluruh rakyat Indonesia.

Pendidikan Kewarganegaraan memiliki posisi yang sangat strategis dalam kurikulum nasional. Tentu posisi tersebut harus dimanfaatkan sebaik mungkin, dengan menggunakan strategi efektif, dalam membentuk mental peserta didik yang memiliki nilai keadilan yang berdasar pada 
Ketuhanan yang Maha Esa dan memiliki moralitas yang tinggi.

Perdebatan seputar titik berat keilmuan yang difokuskan pada aspek pengetahuan atau sikap menjadi problematika klasik pada kajian keilmuan Pendidikan Kewarganegaraan, tentu sebagai disiplin ilmu yang berfokus pada internalisasi nilai-nilai keadilan berdasarkan Ketuhanan yang Maha Esa kepada peserta didik, aspek sikap perlu menjadi prioritas utama keilmuan Pendidikan Kewarganegaran, karena paradigma yang dibangun sejak dulu, peserta didik lebih berfokus pada aspek kognitif atau pengetahuan saja. Paradigma tersebut terbukti tidak tepat, bukti nyata banyak pejabat negara kita yang tertangkap KPK karena telah melakukan tindak pidana korupsi.

Pelaku tindak pidana korupsi bukan seorang individu yang biasa, tindak pidana korupsi membutuhkan jabatan, pengaruh atau kekuasaan, sehingga jelas mengindikasikan bahwa individu yang korupsi merupakan seorang yang cerdas karena mampu menempati jabatan publik yang strategis. fenomena tersebut membuktikan, cerdas saja tidak cukup untuk melengkapi peran individu atas kapasitas sebagai makhluk Tuhan serta sebagai warga Negara, yang turut andil dalam mewujudkan keadilan sosial yang berdasarkan Ketuhanan yang Maha Esa di Indonesia.

Sebagai bangsa modern, perkembangan pendidikan kita telah dipengaruhi oleh keilmuan global seperti filsafat barat dan yang lainnya. Hal tersebut sah saja apabila sesuai dengan nilai-nilai Pancasila, sebagai Negara berfilsafat Pancasila yang menjadikan Ketuhanan sebagai dasar negaranya, tentu dalam konteks pendidikan harus melahirkan manusiamanusia Indonesia yang beriman dan berakhlak mulia. Jelas idealisme tersebut bukan hanya tanggung jawab guru Pendidikan Agama dan Pendidikan Kewarganegaraan tetapi menjadi tanggung jawab semua guru, dan tidak melihat latar belakang keilmuannya.

Rube'i \& Utami (2018 : 310) Menegaskan pancasila memiliki serangkaian nilai, yaitu ketuhanan, kemanusiaan, persatuan, kerakyatan, dan keadilan, yang dijadikan sebagai pedoman warga negara dalam melaksanakan kehidupan berbangsa dan bernegara. Sebagai ideologi bangsa Indonesia Pancasila merupakan sumber utama dalam membuat peraturan tertulis. Sehingga peraturan tertulis tersebut lazimnya tidak bertentangan dengan nilai-nilai yang hidup dalam masyarakat Indonesia.

Pendidikan Kewarganegaraan sebagai pendidikan hukum memiliki hambatan dalam pelaksanaannya yaitu, kualitas sumber daya guru yang kurang memahami konsep hukum yang dimaknai dengan pendekatan filosofi guna mewujudkan keadilan berdasar pada Ketuhanan yang Maha Esa. Problematika mengenai ketidakadilan dalam negeri ini harus menjadi kajian kontekstual dalam memperkaya berbagai teori keilmuan dengan mengkaji fenomena tersebut dengan keilmuannya masing-masing, baik PKn, hukum, politik, sosiologi dan yang lainnya, sebagai sumbangsih pemikiran dalam meningkatkan khazanah keilmuan dan memperluas wawasan peserta didik, sehingga mereka mampu menganalisis, memberi solusi atas permasalahan tersebut.

Pakendek (2017 : 25) menegaskan Indonesia sebagai negara berdasarkan atas Ketuhanan yang Maha Esa, menjamin kemerdekaan warga negara untuk beribadah menurut agamanya dan kepercayaannya sendiri. Keadilan Berdasarkan Ketuhanan yang Maha Esa merupakan intisari dari makna keadilan. Tentu keadilan berdasarkan Ketuhanan yang Maha Esa, harus memperkuat posisi Indonesia sebagai negara multikultural.

Jelas dan perlu dimanfaatkan secara bijaksana, bahwa pembelajaran Pendidikan Kewarganegaraan memiliki posisi strategis 
dalam membentuk moral dan mental siswa yang memiliki keadilan berdasar pada Ketuhanan yang Maha Esa. Hambatan dalam melaksanakan pembelajaran Pendidikan Kewarganegaraan sebagai pendidikan hukum perlu diatasi dengan menggunakan kebijakan yang efektif dari pemerintah, serta ditangani dengan menggunakan solusi yang kreatif dari akademisi Pendidikan Kewarganegaraan maupun organisasi profesi guru Pendidikan Kewarganegaraan.

\section{KESIMPULAN}

Dalam memaknai Keadilan berdasarkan Ketuhanan yang Maha Esa, para pendidik hukum, dan penegak hukum harus memiliki kebijaksanaan dan kehikmatan yang tinggi, sehingga ridho Tuhan membersamai mereka dalam menafsirkan peristiwa hukum.

Pendidikan

Kewarganegaraan memiliki perspektif bahwa penting dalam mengelaborasikan antara konsep Keadilan Berdasar pada Ketuhanan yang Maha Esa dengan keilmuan Pendidikan Kewarganegaraan, guna mendapatkan keadilan yang mampu merepresentasikan nilai-nilai Ketuhanan dalam masyarakat multikultural, karena Pancasila memiliki inti nilai Ketuhanan, maka sudah sewajarnya "keadilan sosial" tujuan akhir dari Pancasila itu sendiri harus berdasarkan pada Ketuhanan yang Maha Esa.

memiliki posisi yang sangat strategis

dalam kurikulum nasional. Tentu posisi tersebut harus dimanfaatkan sebaik mungkin, dengan menggunakan strategi efektif, dalam membentuk mental peserta didik yang memiliki nilai keadilan yang berdasar pada Ketuhanan yang Maha Esa dan memiliki moralitas yang tinggi.

Pendekatan keadilan hukum berdasarkan Ketuhanan yang Maha Esa merupakan kajian filosofi yang menjadi alternatif dalam memahami konsep hukum yang mulai jauh dari nilai-nilai keadilan.

\section{Saran}

1. Memperkuat komitmen penegak dan pendidik hukum dalam menjaga integritasnya dalam melaksanakan penegakan hukum, serta melakukan pendidikan hukum dalam memperjuangkan nilai-nilai keadilan yang diterima secara umum oleh masyarakat Indonesia.

2. Peningatan kapasitas pendidik hukum menjadi strategi efektif dalam mewujudkan keadilan berdasarkan Ketuhanan yang Maha Esa dimasyarakat, dengan cara diberikan akses pendidikan oleh pihak yang berwenang.

3. Pembentukan hukum positif di Indonesia memang berdasar pada Ketuhanan yang Maha Esa, tetapi penegakan hukumnya pun tidak boleh bertentangan semangat Ketuhanan yang Maha Esa.

\section{DAFTAR PUSTAKA}

Lihawa, Y. M. (2018). Penemuan Hukum Islam dalam Mewujudkan Keadilan Berdasarkan Ketuhanan yang Maha Esa. Jurnal Lex Privatum. 6 (6): 5.

Maftuh, B. (2008). Internalisasi Nilai-Nilai Pancasila dan Nasionalisme Melalui Pendidikan Kewarganegaraan. Jurnal Educationist. 2 (2): 137.

Pakendek, A. (2017). Cerminan Keadilan Bermartabat dalam Putusan Pengadilan Berdasarkan Pancasila. Jurnal Yustitia. 18 (1): 25.

Pembukaan Undang-undang Dasar 1945 Pasal 29 Undang-undand Dasar 1945 Tentang Kebebasan Beragama

Rube'i, M. A \& Utami, D. (2018). Penanaman Sila Ketuhanan Yang Maha Esa pada Mata Pelajaran Pendidikan Pancasila dan Kewarganegaraan Kelas XI SMA Negeri 1 Toho Kabupaten Mempawah. Jurnal Pendidikan Kewarganegaraan. 2 (1): 310.

Sulianti, A. (2018). Pendidikan Kewarganegaraan dalam Budaya Multikultural untuk Menanamkan 
Sikap Patriotisme Warga Negara.

Jurnal: Pancasila dan

Kewarganegaraan. 3 (2): 17.

Sutrisno. 2018. Peran Pendidikan Pancasila \&

Kewarganegaraan dalam Menguatkan

Negara Global Citizenship. Jurnal

Pancasila dan Kewarganegaraan 6 (1):

43.

Undang-undang No. 20 Tahun 2003 Tentang

Sistem Pendidikan Nasional 